\title{
Debates on youth participation: from citizens in preparation to active social agents
}

\author{
Maria Tsekoura \\ Pontifícia Universidad Catolica do Chile (UCC)
}

\section{Debates on youth participation: from citizens in preparation to active social agents}

Abstract: This article presents current debates regarding the presence of young people in the public domain. There is a wealth of discussion and perplexity regarding how young people choose to get active in the public domain that originates from the distinct use of the term political in academic and policy debates. This article will proceed in the following way: it will summarise the main tenets of the Decline discourse, it will present how the Personalisation discourse draw our attention to alternative ways of involvement, it will discuss how Context focused discourses highlight how participatory decision making relates to the ways young people conceptualise their daily lived experience, and concludes arguing that youth participation can be better understood when it is contextualised within everyday lived experience.

Key words: Youth. Participation. Decline discourse. Personalisation. Lived experience.

Debates sobre a participação da juventude: de cidadãos em treinamento a agentes da vida social Resumo: Este artigo apresenta debates atuais sobre a presença da juventude na vida pública. Existe um rico debate e muitos questionamentos sobre o modo como os jovens decidem se engajar na vida pública, resultante do uso especial da palavra política nas discussões acadêmicas e sobre políticas públicas. O artigo está assim organizado: em primeiro lugar apresenta uma síntese dos princípios centrais do discurso do Declínio, e depois explicita como o discurso da Personalização salienta formas alternativas de engajamento. A seguir, é analisado o modo pelo qual os discursos focalizados no Contexto enfatizam o modo como os processos participativos de decisão se relacionam com a maneira de jovens conceituarem suas experiências cotidianas. $\mathrm{O}$ artigo conclui afirmando que a participação da juventude pode ser melhor entendida quando contextualizada nas experiências vividas no cotidiano.

Palavras-chave: Juventude. Participação. Discurso do declínio. Personalização. Experiência vivida. 


\section{Introduction}

Youth participation has gained increased visibility within academic debates and public policies in the last decades. The expected outcomes of increased involvement of youth are framed around different and often contradictory agendas. A few examples involve the increase of civic involvement, the prevention of anti-social behaviour, the formation of future active citizens, and the empowerment of young people themselves. These agendas have been developed within the space created by larger sociopolitical and economic shifts that impacted the meaning of citizenship and signaled an increased emphasis on deliberative forms of democracy, social justice issues, recognition of difference, and identity struggles with a parallel introduction of consumerist principles for the improvement of services and the modernization of governance (TISDALL et al., 2008; SINCLAIR, 2004). Matthews (2003) argues that there are three main arguments regarding the purposes of youth participation, which involve interests in providing education for citizenship, fitting young people into society, and reinforcing young people's status in adult society. Summarising discussions in the field of children's participation, Thomas (2007) identifies two dominant discourses within contemporary youth participation. The first discourse is predominantly social and focuses on networks, inclusion, adult-child relations and on the opportunities for social connection that participatory projects can create. The second discourse is more political and stresses issues of "power, challenge and change" (THOMAS, 2007, p. 206). Predominantly, however, citizenship and youth participation discourses connect with the overlapping, and often contradictory, construction of young people as "becoming" or as "democratic citizens in process of formation" on the one side and as "being" or "competent social actors" on the other. Before proceeding with the discussion of contemporary discourses of youth participation it is necessary to pause at this stage in order to ponder over the meaning of the main concepts used in this article such as youth, academic debates, or discourses and consider their relevance to particular contexts.

This article does not stem from a standpoint that conceives young people as a homogeneous group with common needs and aspirations. It rather recognises that young people are active social actors with their own conceptualisations and lived experience, complex identities and social standings. It is, therefore, difficult to provide a clear-cut definition of youth that would describe with accuracy the lived experience of all young people. For the purposes of this article, however, and for achieving some clarity the term young people refers to individuals belonging to the age category 16 to 30 years, a life-stage that is characterized by common challenges regarding opportunities and risks in life domains, such as education, training, employment, welfare, housing, health/mental health issues as well as regarding issues of identity formation. Contemporary understandings of youth and its social role have been developed within an array of disciplines and institutions reflecting shifts from functionalist understandings of youth towards discussions about the multiple dimensions of social experience and the role of the postmodern era and consumerism in shaping young people's experiences. Knowledge or the "truth about youth" has historically been shaped within disciplines such as psychology, sociology, social work and philosophy and has informed the production of state, penal policies and entertainment practices in order to classify the behaviour, regulate, and normalise individuals. Furthermore, as the processes of youth participation involve an array of stakeholders the discourses presented in this article involve not only the contribution of academic actors but also practitioners, policy makers, communities and young people themselves. This is important as the demands laid by the discourse of each actor regarding the purpose of participation have varied implications on the type of procedures put in place to facilitate the involvement of youth.

The increasing interest in the participation of young people reflects wider shifts in understandings of citizenship the last four decades that reconfigured the role of individual citizens within the social domain; owing to the introduction of principles of empowerment, democratic participation, equality and attainment of rights on the one hand and choice, control, active citizenship and consumerism on the other hand (NEWMAN, 2005; JONES; GAVENTA, 2002; JOHANSSON; HVINDEN, 2005). Young people have been reconfigured as "citizens in the making" and, similarly to older generations, are expected now to become volunteers, take part in deliberation processes, vote (when eligible), become members of committees, be partners in the delivery of services, consume services, participate in educational programs and self-regulate (keep themselves out of trouble and more rarely protesting or campaigning).

This article will focus on describing current discourses about youth involvement in the public domain that cut across different disciplines and share a common interest in exploring how young people express their political roles, identities, and perceptions. The analysis involves discourses mainly deriving from western latemodern cultural contexts. However, this discussion can be of use to other cultural contexts since general and abstract perceptions of youth participation - often emerging from international discourses - can find their way to the national level, to merge with other local discourses to provide them a renewed legitimacy (TSEKOURA, 2012). Furthermore, the value of exploring such discourses when discussing youth participation in particular contexts lies in the fact that they have become increasingly relevant among international organizations in their 
effort to promote youth rights, protect young people and force accountability onto governments which fail to incorporate youth voice in their practices (for example the United Nations Convention of the Rights of the Child). This theoretically allows some space for discussion regarding processes, rationale and purpose of youth participation, albeit rooted in the contextual specificity of each country.

Overall, current interdisciplinary discussions on the involvement of young people in the public domain can be located along a range of contrasting ideas. On the one extreme are scholars who advocate a declining interest on the part of young people to engage in public affairs. On the other side are those who question dominant understandings of the 'political' and argue that rather than being apathetic young people are developing novel ways to get involved.

The article proceeds in the following way: it will summarise the main tenets of the Decline discourse, it will present how the Personalisation discourse draws our attention to alternative ways of involvement, it will discuss how Context focused discourses highlight how participatory decision making relates to the ways young people conceptualise their daily lived experience, and concludes arguing that we still need more information on the ways young people organise their lives and make decisions on a daily basis regarding participation.

\section{Decline discourse}

A long established discourse of youth involvement portrays young people as apathetic and disengaged with political processes. This discourse focuses on civic involvement and employs a concept of the political that involves participation in formal political processes. Scholars who advocate a lack of youth participation portray youth as less interested in political matters and less likely to vote, become members of formal organisations such as political parties, and in general as having limited knowledge regarding public issues. Research evidence that confirms declining participation, voting turnout and mistrust of the political system abound across the different national and regional contexts (PARK et al., 2004; PIRIE; WORCESTER, 2000; MELLOR et al., 2002; FLASCO, 2013).

Such concerns over youth apathy or alienation from the democratic processes are reflected in public policies that propose creation of formal participatory opportunities to revitalise civic interest, deal with weakening of social bonds and lack of social capital, and prepare youth for democratic participation (CRICK, 1998). The United Nations Development Program (UNPD, 2013), for example, published a practice guide to promote greater involvement of young people in formal representative processes. The list of suggested practices involves the creation of youth quotas in electoral law and political parties, lowering of the minimal age of eligibility to vote and be elected, promotion of youth participation and civic education in schools and universities, support for local youth councils, support for the development of strong youth party wings, as well as revision of the legal frameworks for youth participation and technical support to governments (UNPD, 2013).

However, such approaches are highly problematic because they both employ a narrow concept of the political (O'TOOLE et al. 2003; MARSH et al. 2007; MANNING, 2010) and adopt a deficit approach to youth (FRANCE, 2007). Regarding the conceptualisation of the political, the advocates of youth apathy draw from the legacy of liberal democracy that constructs social life through binaries such as formalinformal, public-private, proper/real politics-community involvement. There is a conviction in such perspectives that expansion of legislation to include the right to participate in public affairs through formal channels such as voting and engagement with institutions guarantees the unproblematic participation of young people. This is based on a liberal assumption that changes in the legislation can have a direct impact on citizen behaviour. Thus, employing a narrow view of the political to mean engagement with formal institutions and politics (O'TOOLE et al. 2003; MARSH et al. 2007) and legally providing a degree of opportunity to do so, leads to constructing decision to non-participation as apathy and lack of responsibility. However, such liberalist assumptions of involvement that appears to be unfolding on a level playing field underplay the importance of the structural barriers that social groups face in their effort to participate in democratic processes. When this idea is coupled with a long standing discourse of youth as a threat (deficit approach) it results in minimal tolerance for political expression among young people that goes beyond formal structures. Such a "deficit" model (FRANCE, 2007) implies that young people are unwilling to take their responsibilities seriously: they are apathetic or unable to manage risk and thus "less than good citizens" (OSLER; STARKEY, 2003 apud FRANCE, 2007, p. 68). This depoliticizes youth, downplays their experiences and the impact that the social position of each individual may have on their ability to get involved. Furthermore, the voices and perspectives of young people have secondary importance in this type of analysis, "leaving us with a perspective of 'causes' that are defined by the researcher's interpretation and moral judgements" (FRANCE, 2007, p. 37). 


\section{The personalisation discourse}

While there is evidence (often based in quantitative measurements) of a declining trend in formal and collectivist forms of participation (PATTIE et al., 2004; NORRIS, 2003), this does not necessarily indicate alienation and lack of involvement in public affairs. An emerging interdisciplinary discourse aims to locate and describe how the citizens generate new channels of involvement and how these may circumvent traditional forms of involvement. Where others perceive apathy and alienation this body of literature sees novel ways of adapting to the changes caused by the increased pace of socioeconomic change and the ever-increasing complexity in the relationship between citizens and power structures. Conditions created by economic globalisation, marketisation, and privatization have increased risk and instability in daily life. Widening choice in every aspect of life (work, family, entertainment) encompasses increased individual responsibility to make the right decisions in the here and now, fragmenting thus the relationship with groups, networks, and formal institutions. In this way, citizenship is brought down to the daily, informal and local domains of life, in contrast to formal and hierarchical forms of engagement. Citizenship is thus expressed through lifestyle choices, personal values and self-actualisation (GIDDENS, 1991). Political activity is understood as emerging from below (subpolitics) and not as the privilege of state and civil society (BECK, 1994) and the boundaries of the private and public are becoming increasingly blurred in the domain of everyday life. These subpolitics emerge as the governments are unable to manage the risks that people face as a consequence of the recent social and economic transformations. This inability of the state to provide solutions undermines its legitimacy and prevents political institutions from having a meaningful role in citizens' lives and increases mistrust at part of the latter. Besides, challenging those in power has become increasingly difficult since privatisation, deregulation, and marketisation meant that decision making is now taking place in an array of agencies and government agencies have ceased to be directly accountable (NORRIS, 2003).

For Bennet (2012, p. 21) this gives rise to personalised politics. Personalisation is an all-encompassing element of the contemporary era as social, economic and political life: "has been up close and personal, as exemplified by an expanding number of self-help books, multiplying therapeutic talk programs, ever-surprising reality TV genres with their strange assortment of everyday people picked from obscurity to become celebrities, and, everywhere, the consuming emphasis on personal lifestyle affordances as the building blocks for a meaningful life". Accordingly, the political expression of young people differs from that of older generations by employing a distinction between dutiful citizens and self-actualising citizens. Dutiful citizens are involved in traditional politics such as political parties, voting and other government activities. This type of activity, Bennett (2007, p. 62) argues, is more associated with older people. Younger people are more associated with the self-actualizing citizen

Over the last decades we

have come a long way in our understanding of youth as a social group with its own value. However, we still need to develop more knowledge about the ways young people conceive and work towards social change. This would involve looking at developments in youth participation not as an inevitable consequence of the structural changes posed by post-modernity (and which affect all groups of the general population) but also as a conscious effort among youth to produce social change that effects the self, others, and the society in general. seeing "political activities and commitments in highly personal terms that contribute to enhancing the quality of personal life (...) than to understanding, support, and involvement in government".

In this new context, argues Norris $(2002 ; 2003$, p. 16), focusing on traditional repertoires such as patterns of voting and membership, campaign work and contact with elected representatives is a partial and dated perspective that is "no longer mirroring contemporary politics". She suggests that there is a diversification of 
the repertoires (actions commonly used for political expression), and the targets (political actors that participants seek to influence). More than any other social group, young people as a group are more prone to get involved in 'cause-orientated' political repertoires, such as petitioning, consumer boycotts, and demonstrations as they contrast with citizen orientated acts (e.g. elections). Cause-oriented repertoires aim to influence policies and to alter patterns of social behaviour, while they are targeting a diverse number of targets in the public, private and non-profit domains.

Similarly, Bang (1999; 2005) observed an increase of personalised participation in liberal democracies with the younger generations, in particular, having responded to modern changes in novel ways characterised by reflexivity and diverse modes of getting involved. His participants were interested in public issues and informed about politics. However, they preferred to express their political dispositions through the two emerging identities of 'expert citizen' and 'everyday maker'. Expert citizens possessed the necessary expertise (knowledge, skills, communication/negotiation ability) to exercise influence in elite networks. In contrast to the activists of the past, the expert citizens, did not oppose the system, but instead explored opportunities to develop partnerships and access to bargaining processes with public authorities, politicians, interest groups, media and experts from both private and voluntary sector (BANG, 2005). Everyday makers were motivated by their interests rather than duty. While they kept themselves informed about politics, they did not want to get involved in politics or to shape/alter others' identities. Their identity stems mostly from being able to construct networks in their local communities rather than being concerned with 'big' politics.

\section{Context focused approaches}

The approaches looking at the new ways in which citizens understand and express their political identities have successfully questioned existing assumptions about the nature of participation and the political. They have challenged traditional assumptions of citizenship constructed around the formal-informal and passive-active binaries. However, there is still a tendency to present young people as a homogeneous group with common experiences, interests, and identity. Increasingly, a growing body of literature is developing a more reflective attitude and acknowledges that our understanding of youth lives has remained largely descriptive and that we know little about the ways young people make sense of their social role. Even more, we have limited understanding of how choices among youth regarding involvement relate to their daily lived experience and perceptions of their particular contexts.

Latest empirical work highlights two important issues in the discussion of youth participation: first, despite young people being unwilling to fully engage with hierarchical institutions they still want to be recognised and be part of formal institutions; second, a considerable amount of youth participation and expression is taking place within informal domains of daily life. While participation of youth is becoming increasingly personalised at the same time concerns about public issues, the norms that bound communities together and the impact of formal decision-making on individuals and communities are central in young people's narratives (VROMEN et al., 2003; LISTER et al., 2003; BARNES, 2007; MATTHEWS; LIMB, 2003; MARSH et al., 2007, HARRIS et al., 2010, TSEKOURA 2016a; 2016b).

Furthermore, research provides evidence that instead of being alien to networks of power relations of their contexts young people understand their political identities and roles according to their capacity to navigate such networks. Tsekoura (2016a; 2016b) describes how the social histories of the young participants, perceptions of living environments, experience of education, future aspirations and perceptions of relationships with others mediated their strategies of participation. The participants in this study placed increased emphasis on making involvement relevant to their daily lived experience. Soler-i-Martí and Ferrer-Fons (2015) use existing statistical information and surveys to show how the social position of young people in 26 locations in 12 EU countries defines opportunities and impacts their repertoires regarding social participation.

As discussed previously the personalisation discourse, broke down old binaries but is seems to be introducing a new binary to understand involvement: novel-traditional. However, existing evidence in several contexts shows that far from being that clear, processes of youth involvement are more complex and incorporate aspects of different traditions. Juris and Pleyers (2009), for example, in their research with young activists within the global justice movement in Europe and Latin America observe an expansion of the features related to the New Left of the 1960s and the Social Movements of the 1970s alongside more modern ways of involvement that involved use of technology, local-global networking and organizing around aspects of everyday life that relate to diversity, inequality, difference and economic and social justice.

Research in Latin America confirms that more personalised forms of involvement coexist with more traditional forms of expression and concern about collective matters. In Chile, for example, research shows 
that despite a predominant perception among youth that success and personal biography lie within personal responsibility, youth wanted a more active role in public matters and felt "unprotected" by the state in their effort to achieve satisfactory lives (UNAB, 2013). They also held critical views about social issues such as education as a right as it contrasts with a reality of education as a product for consumption (Martínez et al., 2010; 2012), and about restrictions regarding access to public services (SILVA; SILVA, 2010). Similarly, Silva and Romero (2013) observe that the student movements in Chile privileged symbolic action exemplified through creative activities and artistic expressions in the streets. Furthermore, they organize through the use of technology and social media and they value autonomy from political parties and government institutions (BAEZA; SANDOVAL, 2009; OSORIO, 2003).

Such empirical work opens up a discussion that highlights the need for research that looks at how the boundaries between the personal and the public are re-configured in distinct contexts (be it the neighborhood, the city, or the country) and how this might shape new forms and strategies of youth involvement. For as long as we dominantly shape our understandings of involvement through a single paradigm, a wealth of activity that reveals the political dispositions of young people will remain under the radar. This is because the prevailing liberal model frames the political identity and rights of youth in reference to adults within a discourse of "citizens in the making" and "not ready yet to enter" the public domain. This construction leaves out an array of activities attractive to young people such as volunteering, donating, campaigning, work for the environment, that are rarely seen as actual political expressions. Although "unspectacular" (HARRIS et al., 2010) such modes of participation demonstrate that young people understand the important problems in each society and assume an active role to address these issues. From the Australian context Manning (2010) demonstrates how a narrow construction of the "political" around the public-private binary restrains the ability, even among young people themselves, to perceive activity taking place in the daily and local domain as political. This ties in well with the comment of Harris et al. (2010, p. 21) who observed that the participants in their study were "given very little language with which to conceive of their everyday issues as belonging to the same arena as politics".

\section{Conclusion}

In this article I have revised the main debates regarding the political role of young people. Revision of these debates demonstrates that rather than fitting into a category (apathetic-innovators) young people shape their strategies of involvement according to their lived experience and value aspects of both traditional and personalised/reflexive modes of involvement. Over the last decades we have come a long way in our understanding of youth as a social group with its own value. However, we still need to develop more knowledge about the ways young people conceive and work towards social change. This would involve looking at developments in youth participation not as an inevitable consequence of the structural changes posed by post-modernity (and which affect all groups of the general population) but also as a conscious effort among youth to produce social change that effects the self, others, and the society in general. A growing body of current research shows that in order to be able to make sense of the complexity of youth participation it is necessary to adopt a wider concept of the political to incorporate the variety of youth involvement. Moreover, our research focus needs to move to capturing instances/processes of participation that are contextualised within everyday lived experience. In doing so, the focus shifts from a discourse of young people as citizens in preparation to one of young people as active social agents.

\section{References}

BANG, H. Among Everyday Makers and Expert Citizens, In: Newman, J (ed.) Remaking Governance: Peoples, Politics and the Public Sphere. Bristol: Policy Press, p. 159-178, 2005.

BAEZA, J.; SANDOVAL, M. Valores en estudiantes de educación media de la Región Metropolitana. Santiago: CEJU/UCSH, 2009. BARNES, M. Whose Spaces? Contestations and Negotiations in Health and Community Regeneration Fora in the UK', in Cornwall, A. and Coelho, V.S. (Eds) Spaces for Change? The politics of citizen participation in new democratic areas. London: Zed books, p. 240259, 2007.

BECK, U. The reinvention of politics: Towards a theory of reflexive modernization, In: Beck, U., Giddens, A.; Lash, S. (eds.) Reflexive modernization. Politics, tradition and aesthetics in modern social order. Cambridge: Polity Press, p. 1-55,1994.

BENNET, W. L. Civic learning in changing democracies: Challenges for citizenship and civic education, In: DAHLGREN, P. (ed.) Young Citizens and New Media. Learning for democratic participation, Routlegde Studies in Social and Political Thought. New York: Routledge, p. 59-78, 2007. 
. The personalisation of politics: Political Identity, Social Media, and Changing Patterns of Participation, The ANNALS of the American Academy o Political and Social Science 644:20-39, 2012.

CRICK, B. Education for citizenship and the teaching of democracy in schools. Final report of the Advisory Group on Citizenship. QCA. 22 September 1998.

FLASCO. Youth and political participation. In: Latin America. Current state and challenges. Document prepared by FLASCO CHILE for the annual democracy forum: youth participation and elections, November 2013.

FRANCE, A. Understanding Youth in Late Modernity. Maidenhead: Open University Press, 2007.

GIDDENS, A. Modernity and Self-Identity: Self and Society in the Late Modern Age. Cambridge: Polity, 1991 .

HARRIS, A.; WYN, J.; YOUNES, S. Beyond apathetic or activist youth 'Ordinary' young people and contemporary forms of participation, Young, v. 18, n. 1, p. 9-32, 2010.

JOHANSSON, H.; HVINDEN, B. Welfare governance and the remaking of citizenship, In: Newman, J. (Ed) Remaking Governance. Peoples, politics and the public sphere, Bristol: The Policy Press, p. 101-118, 2005.

JONES, E.; GAVENTA, J. Concepts of Citizenship: A Review, IDS Development Bibliography 19, 2002.

JURIS, J.; PLEYERS, G. H. Alter-Activism: Emerging Cultures of Participation among Young Global Justice Activists, The Journal of Youth Studies 12(1): 51-75, 2009.

LISTER, R.; SMITH, N.; MIDDLETON, S.; COX, L. Young People Talk about Citizenship: Empirical Perspectives on Theoretical and Political Debates, Citizenship Studies 7(2): 235-253, 2003.

MANNING, N. Tensions in young people's conceptualisation and practice of politics, Sociological Research Online, 15 (4), 2010.

MARSH, D.; O'TOOLE, T.; JONES, S. Young People and Politics in the United Kingdom: apathy or alienation? Palgrave Macmillan, 2007.

MARTÍNEZ, M. L.; SILVA, C.; HERNÁNDEZ, A. ¿En qué ciudadanía creen los jóvenes? Creencias, aspiraciones de ciudadanía y motivaciones para la participación sociopolítica en jóvenes. Psykhe n. 19, 2010. Santiago: Escuela de Psicología, Pontificia Universidad Católica de Chile.

.; CARMONA, M.; CUMSILLE, M. Young chileans views of citizenship: Findings from the first generation born after the reinstitution of democracy, Applied Developmental Science n. 16(4), 2012.

MATTHEWS, H. Children and Regeneration: Setting an Agenda for Community Participation and Integration, Children and Society 17(4): 264-276, 2003.

.; LIMB, M. Another white elephant? Youth councils as democratic structures, Space and Polity 7(2): 173-192, 2003.

MELLOR, S.; KENNEDY, K.; GREENWOOD, L. Citizenship and Democracy: Australian

Students' Knowledge and Beliefs. The IEA Civic Educational Study of Fourteen Year Olds, Melbourne: Australian Council for Educational Research, 2002.

NEWMAN, J. Participative governance and the remaking of the public sphere, In: Newman, J. (Ed) Remaking Governance. Peoples, politics and the public sphere, Bristol: The Policy Press, p.119-138, 2005.

NORRIS, P. Democratic Phoenix: Reinventing Political Activism. Cambridge University Press, 2002.

. Young People \& Political Activism: From the Politics of Loyalties to the Politics of Choice? John F. Kennedy School of Government Harvard University. Report for the Council of Europe Symposium: 'Young people and democratic institutions: from disillusionment to participation'. Strasbourg, 27-28th November 2003.

OSORIO, C. Las nuevas formas de acción colectiva: nuevos movimientos contestatarios juveniles en Santiago de Chile. Informe final del concurso. Movimientos sociales y nuevos conflictos en América Latina y el Caribe. Programa Regional de Becas CLACSO, 2003. O’TOOLE, T.; LISTER, M.; MARSH, D.; JONES, S.; MCDONOUGH, A. Tuning out or left out? Participation and non-participation among young people, Contemporary Politics 9(1): 45-61, 2003.

PARK, A.; PHILLIPS, M.; JOHNSON, M. Young People in Britain: The Attitudes and Experiences of 12 to 19 year olds, Nottingham: Department for Education and Skills, 2004.

PATTIE, C.; SEYD, P.; WHITELEY, P. Citizenship, Democracy and Participation. In: Contemporary Britain. Cambridge University Press, 2004.

PIRIE, M.; WORCESTER, R. M. The Big Turn-off: Attitudes of Young People to Government, Citizenship and Community. London: Adam Smith Institute, 2000.

SILVA, C.; ROMERO, J. ¿Qué es un movimiento social fuerte? Conceptualizaciones de la noción de fortaleza y aplicación al caso del movimiento estudiantil 2002-2011 en Chile Última Década. Valparaíso, n. 38, p. 91-108, Julio 2013.

.; SILVA, E. La economía política y las motivaciones de participación sociopolítica de jóvenes chilenos: una interpretación de los hallazgos de Martínez, Silva y Hernández. Psykhe n. 19(2), 2010. Santiago: Escuela de Psicología, Pontificia Universidad Católica de Chile.

SINCLAIR, R. Participation in Practice: Making it Meaningful, Effective and Sustainable Children and Society 8, p.106-118, 2004. THOMAS, N. Towards a Theory of Children's Participation, International Journal of Children's Rights 15, p. 199-218, 2007.

SOLER-I-MARTÍ, R.; FERRER-FONS, M. Youth participation in context: the impact of youth transition regimes on political action strategies in Europe, The Sociological Review, 63:S2, p. 92-117, 2015.

TISDALL, K. E.; DAVIS, J.; GALLAGHER, M. Reflecting on Children and Young People's Participation in UK, International Journal of Children's Rights 16, p. 343-354, 2008. 
TSEKOURA, M. Joining the adventure? Exploring young people's experience within spaces for youth participation in the United Kingdom and Greece. PhD Thesis, University of Birmingham, Birmingham- UK, 2012.

'Adventurers', 'Visionaries' and 'Professionals': Navigating opportunities for youth participation in the UK and Greece, In: THIJSSEN, P.; SIONGERS, J.; VAN LAER, J.; HAERS, J.; MELS, S. (eds). Political Engagement of the Young in Europe: Youth in the Crucible. Routledge Studies in Governance and Public Policy. Routledge: Abingdon, 2016a.

. Spaces for youth participation and youth empowerment: case studies from the UK and Greece. YOUNG, 24.4, $2016 \mathrm{~b}$.

UNAB (Universidad Andrés Bello). Generación Milenio. Encuesta a Jóvenes 2013. Facultad de Ciencias Sociales, Universidad Andrés Bello, Santiago Chile, Diciembre 2013.

UNPD. Enhancing youth political participation. A good practice guide. United nations Development Programme, New York, January 2013.

VROMEN, A. People try to put us down...participatory citizenship of Generation X, Australian Journal of Political Science 38(1), p. 79-99, 2003.

\section{Maria Tsekoura}

matsekoura@uc.cl

Professora na Escola de Serviço Social Faculdade de Ciências Sociais, Pontifícia Universidade Católica de Chile.

PhD em Política Social, Birmingham University - UK

\section{Pontificia Universidad Católica de Chile}

Av. Vicuña Mackenna, 4860

Macul - Santiago - Chile

CP: 7820436 